\title{
Patterns of floral allocation along an elevation gradient: variation in Senecio subalpinus growing in the Tatra Mountains
}

\author{
Piotr Kiełtyk ${ }^{1}$ (D)
}

Received: 18 December 2020 / Accepted: 30 January 2021 / Published online: 1 March 2021

(c) The Author(s) 2021

\begin{abstract}
This study examined the morphological variation in Senecio subalpinus W.D.J. Koch. (Asteraceae) along a 950-m elevation gradient in the Tatra Mountains, Central Europe, with emphasis on floral allocation patterns. Fifteen morphological traits were measured in 200 plants collected in the field from 20 sites then the findings were modelled by elevation using linear mixed-effects models. Plant aboveground biomass and height decreased steadily with increasing elevation; however, the most distinctive feature was the elevational shift in floral allocation patterns. Low-elevation plants had greater numbers of smaller flower heads with a lower overall number of flowers, while high-elevation plants had smaller numbers of bigger flower heads and a greater overall number of flowers. Accordingly, the mean individual flower mass increased significantly with increasing elevation. Interestingly, the width of the outer ligulate flowers also increased considerably with increasing elevation, increasing the fill of the overall circumference of the flower head. Results of this study confirmed that elevation is an important ecological gradient driving variation in vegetative and floral traits of S. subalpinus. Possible causes of the observed variations are subsequently discussed, including the varying effects of both abiotic and biotic factors with elevation gradients.
\end{abstract}

Keywords Altitudinal gradient $\cdot$ Asteraceae $\cdot$ Biomass $\cdot$ Floral characteristic $\cdot$ Morphological variation

\section{Introduction}

Populations of plant species inhabiting mountain slopes are exposed to differing abiotic and biotic conditions along the elevation gradient in which they exist, which can be particularly challenging in those with the wide elevational distribution. The most pronounced changes associated with increasing elevation in temperate mountain regions include decreases in temperature, increased light intensity and UV radiation, shortening of the growing season, increased precipitation, and increases in strong wind frequency (Körner 2003; Nagy and Grabherr 2009). Meanwhile, intraspecific morphological variation associated with these changes include a reduced overall size (Alexander et al. 2009; Zhu et al. 2010; Maad et al. 2013; Paudel et al. 2019), more intensive clonal growth (Št'astná et al. 2012) and a longer

Piotr Kiełtyk

kieltyk@wp.pl

1 Institute of Biological Sciences, Cardinal Stefan Wyszyński University in Warsaw, Wóycickiego 1/3, 01-938 Warszawa, Poland life span (von Arx et al. 2006; ك̌t'astná et al. 2012), as well as smaller numbers of larger flowers (Kelly 1998; Kudo and Molau 1999; Malo and Baonza 2002; Herrera 2005; Maad et al. 2013; Gabel et al. 2017; He et al. 2017) and heavier seeds (Kudo and Molau 1999; Alexander et al. 2009; Wu et al. 2011; Qi et al. 2015). However, decreases in flower size (Totland 2001; Zhao and Wang 2015) and seed mass (Totland 2004; Wirth et al. 2010) with increasing elevation have also been reported, suggesting that the pattern of reproductive allocation is species specific or context dependent.

Reduced overall plant size with increasing elevation can result from plastic responses to the limiting climatic conditions at high altitudes (e.g. Dai et al. 2017; Hamann et al. 2017; Henn et al. 2018); however, it can also result from genetic adaptation to locally prevailing conditions (e.g. Byars et al. 2007; Gonzalo-Turpin and Hazard 2009; Morente-López et al. 2020). Smaller plants have lower resource requirements (Herrera 2005) and are less exposed to harsh climatic conditions such as strong winds (Takahashi 2014), suggesting a climatic selection of smaller phenotypes that are more advantageous in the growth-constraining environments of higher elevations. Meanwhile, the increased 
flower size observed in insect-pollinated plants growing at high elevations, where pollinator density and visitation rates are lower than at low elevations (Arroyo et al. 1985; Blionis and Vokou 2001; Totland 2001), has been explained by pollinator selection (Maad et al. 2013). Larger flowers increase the chances of pollination (Totland 2004), thereby increasing the chances of producing viable seeds and achieving successful sexual reproduction (Arroyo et al. 1982; Ohara and Higashi 1994; Bingham and Orthner 1998). However, a decrease in flower size in growth-limiting high-elevation habitats is thought to represent adaptation and abiotic selection for smaller flowers, due to the lower costs of developing and maintaining smaller floral structures (Herrera 2009). Furthermore, non-linear variations in plant traits may also be generated along elevation gradients in response to different selective pressures at opposite ends of the species elevation range (Frei et al. 2014). For example, a maximum flower size has been found within the middle elevation range of some species (Malo and Baonza 2002; Kiełtyk 2018; Seguí et al. 2018), possibly as a result of the trade-off between pollinator selection for larger flowers at higher elevations (Totland 2001, 2004; Malo and Baonza 2002; Maad et al. 2013) and abiotic selection for less costly smaller flowers under the stressful high-elevation conditions (Herrera 2009; Zhao and Wang 2015).

Understanding the performance of mountain plants in their natural populations across different elevation gradients is gaining increasing attention (e.g. Dai et al. 2017; He et al. 2017; Seguí et al. 2018; Paudel et al. 2019; Bucher and Römermann 2020). The findings will help us understand how plants have adapted to life on steep environmental gradients, while allowing us to predict mountain plant responses to climatic change, particularly in cold environments (Frei et al. 2010; Theurillat and Guisan 2001). This study examined the morphological variation in Senecio subalpinus W.D.J. Koch. in its natural habitat along a 950-m elevation gradient in the Tatra Mountains of Central Europe, focusing on floral allocation patterns. The aim is to provide a better understand the morphological responses of plants to environmental factors associated with elevation gradients, specifically: (1) the relationships between morphological traits and elevation, and (2) the patterns of elevational variation in vegetative and floral traits in S. subalpinus.

\section{Materials and methods}

\section{Study species}

Senecio subalpinus W.D.J. Koch (Asteraceae) is a perennial plant found widespread in the Carpathians, Eastern Alps and mountains of the Balkan Peninsula, mainly in the montane and subalpine vegetation belts (Kucowa 1971; Chater and Walters 1976; Aeschimann et al. 2004). The species grows predominantly in tall-herb vegetation, fresh meadows and pastures, river and stream banks and in forest glades and clearings, mostly on eutrophic and wet soils (Aeschimann et al. 2004). S. subalpinus has its phytosociological optimum in subalpine tall grass vegetation representing the Mulgedio-Aconitetea class (Aeschimann et al. 2004). The stem of S. subalpinus is erect, typically (25) 30-70 (90) cm long, usually branched only at inflorescences and leafy throughout, with leaves gradually decreasing in size up the stem (Kucowa 1971; Chater and Walters 1976). Flower heads are (3) 5-20 in number, $25-40 \mathrm{~mm}$ in diameter and form a corymb. The flowers are yellow or orange-yellow in colour, gathered in a flower head with outer female and inner hermaphrodite flowers, and are insect-pollinated.

\section{Study area}

The field study was conducted in 2017 and 2018 in the Tatra Mountains and its foothills in southern Poland, at elevations of 840-1790 m above sea level (a.s.l.). Permission for the study was obtained from Tatra National Park (Bot/380 DBN. 503/51/17 in 2017 and Bot/380 DBN. 503/28/18 in 2018). The Tatras are the highest range in the Carpathian Mountains (highest peak, Gerlach: $2655 \mathrm{~m}$ a.s.l.), and the only alpine-type mountain system with a well-developed subnival zone between the Alps and the Caucasus. The elevational range of the Polish Tatras traverses through five vegetation belts: a lower montane forest (up to $1220-1250 \mathrm{~m}$ a.s.1.), upper montane forest (1250-1550 m a.s.l.), subalpine belt (1550-1800 m a.s.l.), alpine belt (1800-2300 $\mathrm{m}$ a.s.l), and subnival belt (above $2300 \mathrm{~m}$ a.s.l.) (Mirek and PiękośMirkowa 1992).

\section{Field sampling and morphological measurements}

A total of 200 flowering plants of S. subalpinus were collected from 20 elevational sites (10 plants per site; Online Appendix Figure S1, Table S1). The elevation at each site was determined in the field using a GPS receiver with builtin barometric altimeter (Garmin GPS MAP 76 s, Olathe, USA). At each site, aboveground parts of 10 individual plants at peak blossom were collected, providing a quasirandom sample of well-developed plants showing unrestricted growth and active reproduction. Each sampled plant was ca. $1.5 \mathrm{~m}$ or more from other samples to ensure that each represented a different genetic individual.

A total of 15 morphological traits were examined in each plant (Online Appendix Table S2, raw data measurements 
available in ESM_1). The first measurement was the flower head diameter, which was measured using digital callipers in one randomly selected, well-developed head per plant immediately after collection. Plants were then dried in a botanical press and preserved for further analyses. Plant height was determined as the length from the base of the stem to the top of the inflorescence then the samples were separated into three fractions (stem, leaves and flower heads) and dried for $48 \mathrm{~h}$ at $80^{\circ} \mathrm{C}$ in the laboratory to obtain the dry matter content (PérezHarguindeguy et al. 2013) using an analytical balance. One randomly selected, well-developed head per plant was then soaked in water in a Petri dish for $1 \mathrm{~h}$ before separating into ligulate and tubular flowers. The flowers were then counted using a stereoscopic microscope, and the width of the ligule, and lengths of the ligulate and tubular flowers were measured. The number of ligulate and tubular flowers was counted directly in one randomly selected flower head per plant, and the sizes of the ligulate and tubular flowers were measured in one randomly sampled flower from the head. After measurement, the flowers were stored in paper envelopes and dried for $48 \mathrm{~h}$ at $80^{\circ} \mathrm{C}$ in a drying oven to obtain the dry matter content using an analytical balance. All weight measurements were carried out immediately after the samples were removed from the oven.

\section{Statistical analyses}

All statistical analyses were performed using $\mathrm{R}$ version 4.0.3 ( $\mathrm{R}$ Core Team 2020). Morphological variations in the 15 traits were analysed with linear mixed-effects models using the lmer() function in the lme4 package (Bates et al. 2015). In these models, elevation was used as a continuous variable and treated as a fixed effect, while the sample site was set as a random component. The $95 \%$ confidence intervals of each model were extracted from the lmer object using the plot_model() function available in the sjPlot package (Lüdecke 2020). For each trait, the following two models were obtained: a straightline model and one with an added quadratic term for elevation (i.e., a model with a second order polynomial). These curvilinear models were used to account for the possibility that the relationships between morphological trait variations and elevation may be better described by an optimum curve (a quadratic term). Comparisons of model fit were then carried out using the anova() function based on a likelihood ratio test, where a significant Chi-Squared statistic at $p=0.05$ indicated significant improvement in the linear model upon addition of the quadratic term for elevation (Dalgaard 2008). Accordingly, none of the curvilinear models (i.e., those with a second-order polynomial term) showed a better fit than the straight-line model. Only the results of the straight-line mixedeffects models are therefore presented.

\section{Results}

Traits related to plant size; namely, height, total aboveground biomass and total leaf mass, as well as the number of flower heads per plant, decreased considerably with increasing elevation (Fig. 1a, b, c, d; Table 1). In contrast, most of the floral traits; namely, the mean mass of the flower head, number of ligulate flowers, total respective masses of ligulate and tubular flowers in the head, mean individual flower mass, and ligulate flower width increased significantly with increasing elevation (Fig. 1f, g, j, k, 1, n; Table 1). However, no statistically significant correlations were observed between elevation and the total flower head mass, the number of tubular flowers in the head, flower head diameter, and ligulate and tubular flower lengths (Fig. 1e, h, i, m, o; Table 1).

\section{Discussion}

The results of this study show that elevation is an important factor driving morphological variation in S. subalpinus. Significant changes in a number of morphological traits were observed across the 950-m elevation gradient, with notable decreases in vegetative traits such as plant height, total aboveground biomass and total leaf mass as the elevation increased. These findings are consistent with the common patterns associated with plant size reductions in other mountainous plant species (e.g. Alexander et al. 2009; Zhu et al. 2010; Maad et al. 2013; Paudel et al. 2019). Studies based on the transplantation of plants originating from different elevations to common garden plots, or reciprocal transplantation to plots located at different elevations, confirm that both phenotypic plasticity and local adaptation can have an effect on plant morphology across different elevation gradients (e.g. Byars et al. 2007; Gonzalo-Turpin and Hazard 2009; Hautier et al. 2009; Scheepens et al. 2010; Hirano et al. 2017). The smaller S. subalpinus phenotypes observed at higher elevations may therefore be partly the result of individual phenotypic plasticity under stressful climatic conditions, such as low temperatures and a shortened growing season, and partly due to selection of smaller more compact plants that are more resistant to strong winds (Takahashi 2014) and have lower resource requirements (Herrera 2005).

The most distinctive feature of the elevational variation in $S$. subalpinus was the shift in floral allocation patterns, whereby the number of flower heads decreased considerably with increasing elevation, and the mean mass of the flower head increased significantly. However, because 

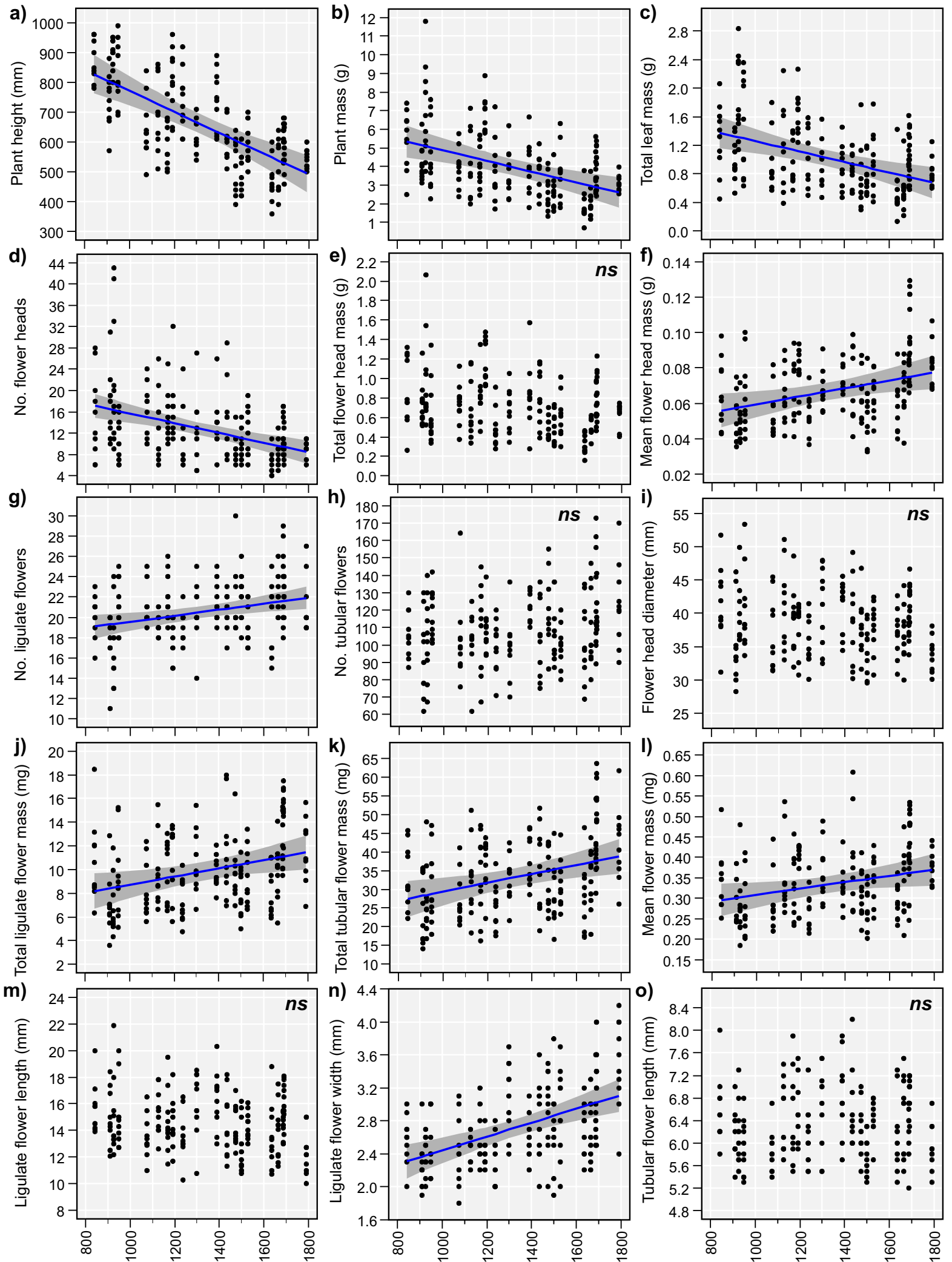

Elevation (m a.s.I.) 
४Fig. 1 Elevational variation in morphological traits of Senecio subalpinus. Solid lines represent the results of the mixed-effects models, while the surrounding grey band represents the $95 \%$ confidence interval. $n s$ not statistically significant at $p=0.05$. A summary of the linear mixed-effects models is presented in Table 1 , and a detailed description of each trait examined is given in Online Appendix Table S2

no significant relationship was detected between the total flower head mass and elevation, the increase was thought to be compensation for the decreased number of flower heads, thereby resulting in an approximately steady gross mass investment in reproduction through floral organ development across the elevation gradient. Meanwhile, a decrease in the number of flower heads with increasing elevation has also been reported in other species in the Asteraceae family (Kelly 1998; Alexander et al. 2009; Kiełtyk 2018), while Takahashi and Matsuki (2016) found a similar elevational shift in floral allocation in Solidago virgaurea s.l., with plants growing at higher elevations showing smaller numbers of larger flower heads compared to low-elevation plants. The increase in the mean flower head mass of $S$. subalpinus with increasing elevation was the result of an increase in the total mass of flowers, both ligulate and tubular. Meanwhile, the increase in total flower mass with increasing elevation was the result of an increase in the total number of flowers in the head, as well as an increase in the mean individual flower mass.
Notably, the width of the outer ligulate flowers increased considerably with increasing elevation, in line with previous results in other Asteraceae species, such as Solidago minuta (Kiełtyk 2018). The wider ligule flowers increased the fill of the overall flower head circumference, thereby increasing the overall flower display area, which can be advantageous in attracting pollinators in the pollinatorlimited conditions of high elevations.

The observed shift in floral allocation patterns in S. subalpinus is thought to be the result of varying selective pressures caused by both abiotic and biotic factors. By producing fewer but larger flower heads with a greater number of flowers, high-elevation plants can reduce their investment in structural elements, such as the flower head stalk, involucre and receptacle. Moreover, because a greater number of flowers is gathered in a single flower head, the unit cost for development and maintenance is also reduced compared to the cost allocation of larger numbers of smaller flowers. Accordingly, the decrease in flower head number and increase in flowers per head in S. subalpinus with increasing elevation may enable more efficient utilisation of the limited resources. A further possible advantage of larger flower heads composed of greater numbers of flowers is enhanced protection against unfavourable climatic conditions, such as strong winds, as well as increased heat radiation from the flower head. Meanwhile, biotic factors may also be responsible for the floral allocation shift in S. subalpinus. Production

Table 1 Summaries of linear mixed-effects models for fitting Senecio subalpinus traits to elevation

\begin{tabular}{|c|c|c|c|c|c|c|c|c|c|}
\hline & Intercept (a) & Slope $b_{1}$ & SE & $t$ & $p$ value & & $\begin{array}{l}\text { Fitted value } \\
\text { at } 840 \mathrm{~m} \\
\text { a.s.1 }\end{array}$ & $\begin{array}{l}\text { Fitted value } \\
\text { at } 1790 \mathrm{~m} \\
\text { a.s. } 1\end{array}$ & $\begin{array}{l}\text { Change } \\
840-1790 \mathrm{~m} \\
\text { a.s.1. (\%) }\end{array}$ \\
\hline Plant height (mm) & $1.1226 \times 10^{+3}$ & $-3.5087 \times 10^{-1}$ & $5.765 \times 10^{-2}$ & -6.09 & 0.0000 & & 827.95 & 494.62 & -40 \\
\hline Plant mass (g) & $7.7628 \times 10^{+0}$ & $-2.8822 \times 10^{-3}$ & $7.667 \times 10^{-4}$ & -3.76 & 0.0014 & & 5.34 & 2.60 & -51 \\
\hline Total leaf mass (g) & $1.9951 \times 10^{+0}$ & $-7.351 \times 10^{-4}$ & $2.008 \times 10^{-4}$ & -3.66 & 0.0018 & & 1.38 & 0.68 & -51 \\
\hline Number of flower heads & $2.4761 \times 10^{+1}$ & $-9.083 \times 10^{-3}$ & $2.046 \times 10^{-3}$ & -4.44 & 0.0003 & & 17.13 & 8.50 & -50 \\
\hline Total flower head mass (g) & $1.0866 \times 10^{+0}$ & $-2.876 \times 10^{-4}$ & $1.449 \times 10^{-4}$ & -1.98 & 0.0625 & ns & - & - & - \\
\hline Mean flower head mass (g) & $3.722 \times 10^{-2}$ & $2.236 \times 10^{-5}$ & $8.660 \times 10^{-6}$ & 2.58 & 0.0188 & & 0.056 & 0.077 & +38 \\
\hline Number of ligulate flowers & $1.66 \times 10^{+1}$ & $2.961 \times 10^{-3}$ & $1.036 \times 10^{-3}$ & 2.86 & 0.0105 & & 19.09 & 21.90 & +15 \\
\hline Number of tubular flowers & $9.0616 \times 10^{+1}$ & $1.346 \times 10^{-2}$ & $6.489 \times 10^{-3}$ & 2.07 & 0.0527 & ns & - & - & - \\
\hline Flower head diameter (mm) & $4.1275 \times 10^{+1}$ & $-2.222 \times 10^{-3}$ & $1.928 \times 10^{-3}$ & -1.15 & 0.2640 & ns & - & - & - \\
\hline $\begin{array}{l}\text { Total ligulate flower mass } \\
(\mathrm{mg})\end{array}$ & $5.3035 \times 10^{+0}$ & $3.425 \times 10^{-3}$ & $1.354 \times 10^{-3}$ & 2.53 & 0.0210 & & 8.18 & 11.43 & +40 \\
\hline $\begin{array}{l}\text { Total tubular flower mass } \\
(\mathrm{mg})\end{array}$ & $1.7442 \times 10^{+1}$ & $1.191 \times 10^{-2}$ & $4.347 \times 10^{-3}$ & 2.74 & 0.0134 & & 27.45 & 38.76 & +41 \\
\hline Mean flower mass (mg) & $2.309 \times 10^{-1}$ & $7.753 \times 10^{-5}$ & $3.612 \times 10^{-5}$ & 2.15 & 0.0457 & & 0.296 & 0.370 & +25 \\
\hline $\begin{array}{l}\text { Ligulate flower length } \\
(\mathrm{mm})\end{array}$ & $1.6112 \times 10^{+1}$ & $-1.165 \times 10^{-3}$ & $8.218 \times 10^{-4}$ & -1.42 & 0.1730 & ns & - & - & - \\
\hline Ligulate flower width (mm) & $1.5991 \times 10^{+0}$ & $8.41 \times 10^{-4}$ & $1.834 \times 10^{-4}$ & 4.58 & 0.0002 & & 2.31 & 3.10 & +35 \\
\hline Tubular flower length (mm) & $6.23 \times 10^{+0}$ & $9.022 \times 10^{-5}$ & $2.681 \times 10^{-4}$ & 0.34 & 0.7400 & ns & - & - & - \\
\hline
\end{tabular}

significance level $=0.05 ; n s$ not statistically significant 
of heavier larger flower heads with a greater number of flowers may increase the chance of pollination at higher elevations, where pollinators are scarce, thereby increasing the chance of successful reproduction (Bingham and Orthner 1998). However, large flower heads can simultaneously advertise the availability of resources to pre-dispersal seed predators, since bud infestation has also been found to increase with increasing flower head size (Fenner et al. 2002; Weppler and Stöcklin 2006). Overall, therefore, a greater number of smaller flower heads in S. subalpinus may be advantageous at lower elevations where pollinator selection is not particularly intensive due to the higher number of pollinators, although the risk of herbivore damage is generally greater (Scheidel and Bruelheide 2001; Moreira et al. 2018). Meanwhile, a greater number of flower heads with fewer flowers per head may balance the risk of flower and seed damage from herbivores or pre-dispersal seed predators at lower elevations. From the viewpoint of biotic interactions, therefore, flower head number and size at a given elevation are thought to represent a trade-off between the opposing selection pressures of pollination and pre-dispersal seed predation (Fenner et al. 2002). It should be noted, however, that although the general assumption is that herbivorous insect pressure is stronger under the warmer conditions of low elevations (Moreira et al. 2018), little is currently known about the elevational variation in selective pressures exerted by pre-dispersal seed predators (e.g. Kelly 1998).

In conclusion, this study confirmed that elevation is an important ecological gradient driving variation in vegetative and floral traits of S. subalpinus. Although this study was unable to determine the reason for the smaller number of larger flowers at higher elevations, this pattern is thought to be related to reproductive success in local populations at different elevations. Further analysis of the degree to which these changes represent genetic differences among locally adapted populations or plastic, environmentally induced responses across the elevation gradient are now required.

Supplementary Information The online version contains supplementary material available at https://doi.org/10.1007/s00035-021-00247-w.

Acknowledgements I am grateful to Wiesława Kiełtyk for help in the field study. Two anonymous reviewers provided helpful comments on earlier drafts of the manuscript. I thank the Research Department of the Tatra National Park for providing kind support and research permission.

Author contributions PK conceived the idea of the study, collected, measured and analysed the data, and wrote the manuscript.

Funding Financial support was provided by the Cardinal Stefan Wyszyński University in Warsaw.

Data availability Data are available in Electronic Supplementary Material 1 (ESM_1.xlsx).

\section{Compliance with ethical standards}

Conflict of interest Author declares no conflict of interest.

Open Access This article is licensed under a Creative Commons Attribution 4.0 International License, which permits use, sharing, adaptation, distribution and reproduction in any medium or format, as long as you give appropriate credit to the original author(s) and the source, provide a link to the Creative Commons licence, and indicate if changes were made. The images or other third party material in this article are included in the article's Creative Commons licence, unless indicated otherwise in a credit line to the material. If material is not included in the article's Creative Commons licence and your intended use is not permitted by statutory regulation or exceeds the permitted use, you will need to obtain permission directly from the copyright holder. To view a copy of this licence, visit http://creativecommons.org/licenses/by/4.0/.

\section{References}

Aeschimann D, Lauber K, Moser DM, Theurillat J-P (2004) Flora alpina. Haupt Verlag, Bern

Alexander JM, Edwards PJ, Poll M, Parks CG, Dietz H (2009) Establishment of parallel clines in traits of native and introduced forbs. Ecology 90:612-622. https://doi.org/10.1890/08-0453.1

Arroyo MTK, Primack RB, Armesto JJ (1982) Community studies in pollination ecology in the high temperate Andes of central Chile. I. Pollination mechanisms and altitudinal variation. Am J Bot 69:82-97. https://doi.org/10.1002/j.1537-2197.1982.tb13237.x

Arroyo MTK, Armesto JJ, Primack RB (1985) Community studies in pollination ecology in the high temperate Andes of Central Chile II. Effect of temperature on visitation rates and pollination possibilities. Pl Syst Evol 149:187-203. https://doi.org/10.1007/ BF00983305

Bates D, Maechler M, Bolker B, Walker S (2015) Fitting linear mixedeffects models using lme4. J Stat Soft 67:1-48. https://doi:https:// doi.org/10.18637/jss.v067.i01

Bingham RA, Orthner AR (1998) Efficient pollination of alpine plants. Nature 391:238-239. https://doi.org/10.1038/34564

Blionis GJ, Vokou D (2001) Pollination ecology of Campanula species on Mt Olympos, Greece. Ecography 24:287-297. https://doi.org/ 10.1034/j.1600-0587.2001.240306.x

Bucher SF, Römermann Ch (2020) Flowering patterns change along elevational gradients and relate to life-history strategies in 29 herbaceous species. Alp Bot 130:41-58. https://doi.org/10.1007/ s00035-020-00231-w

Byars SG, Papst W, Hoffmann AA (2007) Local adaptation and cogradient selection in the alpine plant, Poa hiemata, along a narrow altitudinal gradient. Evolution 61:2925-2941. https:// doi.org/10.1111/j.1558-5646.2007.00248.x

Chater AO, Walters SM (1976) Senecio L. In: Tutin TG, Heywood VH, Burges NA, Moore DM, Valentine DH, Walters SM, Webb DA (eds) Flora Europaea 4. Cambridge University Press, London, pp 191-205

Dai WK, Amboka GM, Kadiori EL, Wang QF, Yang CF (2017) Phenotypic plasticity of floral traits and pollination adaptation in an alpine plant Pedicularis siphonantha D. Don when transplanted from higher to lower elevation in Eastern Himalaya. J Mt Sci 14:1995-2002. https://doi.org/10.1007/s11629-017-4481-1

Dalgaard P (2008) Introductory statistics with R, 2nd edn. Springer Science+Business Media, LLC, New York

Fenner M, Cresswell JE, Hurley RA, Baldwin T (2002) Relationship between capitulum size and pre-dispersal seed predation 
by insect larvae in common Asteraceae. Oecologia 130:72-77. https://doi.org/10.1007/s004420100773

Frei E, Bodin J, Walther GR (2010) Plant species' range shifts in mountainous areas-all uphill from here? Bot Helv 120:117128. https://doi.org/10.1007/s00035-010-0076-y

Frei ER, HahnT GJ, Pluess AR (2014) Divergent selection in low and high elevation populations of a perennial herb in the Swiss Alps. Alp Bot 124:131-142. https://doi.org/10.1007/s0003 5-014-0131-1

Gabel ER, Sattler J, Reisch Ch (2017) Genetic variation and performance of the alpine plant species Dianthus callizonus differ in two elevational zones of the Carpathians. Alp Bot 127:65-74. https://doi.org/10.1007/s00035-016-0177-3

Gonzalo-Turpin H, Hazard L (2009) Local adaptation occurs along altitudinal gradient despite the existence of gene flow in the alpine plant species Festuca eskia. J Ecol 97:742-751. https:// doi.org/10.1111/j.1365-2745.2009.01509.x

Hamann E, Scheepens JF, Kesselring H, Armbruster GFJ, Stöcklin J (2017) High intraspecific phenotypic variation, but little evidence for local adaptation in Geum reptans populations in the Central Swiss Alps. Alp Bot 127:121-132. https://doi.org/10.1007/s0003 5-017-0185-y

Hautier Y, Randin ChF, Stöcklin J, Guisan A (2009) Changes in reproductive investment with altitude in an alpine plant. J Plant Ecol 2:125-134. https://doi.org/10.1093/jpe/rtp01

He JD, Xue JY, Gao J, Wang J, Wu Y (2017) Adaptations of the floral characteristics and biomass allocation patterns of Gentiana hexaphylla to the altitudinal gradient of the eastern Qinghai-Tibet Plateau. J Mt Sci 14:1563-1576. https://doi.org/10.1007/s1162 9-017-4424-X

Henn JJ, Buzzard V, Enquist BJ, Halbritter AH, Klanderud K, Maitner BS, Michaletz ST, Pötsch Ch, Seltzer L, Telford RJ, Yang Y, Zhang L, Vandvik V (2018) Intraspecific trait variation and phenotypic plasticity mediate alpine plant species response to climate change. Front Plant Sci 9:1548. https://doi.org/10.3389/ fpls. 2018.01548

Herrera J (2005) Flower size variation in Rosmarinus officinalis: individuals, populations and habitats. Ann Bot 95:431-437. https:// doi.org/10.1093/aob/mci041

Herrera J (2009) Visibility vs. biomass in flowers: exploring corolla allocation in Mediterranean entomophilous plants. Ann Bot 103:1119-1127. https://doi.org/10.1093/aob/mcp046

Hirano M, Sakaguchi S, Takahashi K (2017) Phenotypic differentiation of the Solidago virgaurea complex along an elevational gradient: insights from a common garden experiment and population genetics. Ecol Evol 7:6949-6962. https://doi.org/10.1002/ece3.3252

Kelly CA (1998) Effects of variable life history and insect herbivores on reproduction in Solidago macrophylla (Asteraceae) on an elevational gradient. Am Midl Nat 139:243-254. https://doi. org/10.1674/0003-0031(1998)139[0243:EOVLHA]2.0.CO;2

Kiełtyk P (2018) Variation of vegetative and floral traits in the alpine plant Solidago minuta: evidence for local optimum along an elevational gradient. Alp Bot 128:47-57. https://doi.org/10.1007/s0003 5-017-0197-7

Körner Ch (2003) Alpine plant life. Functional plant ecology of high mountain ecosystems, 2nd edn. Springer-Verlag, Berlin

Kucowa I (1971) Senecio L. In: Pawłowski B, Jasiewicz A (eds) Flora Polska, vol 12. Państwowe Wydawnictwo Naukowe, Warszawa, pp 320-351

Kudo G, Molau U (1999) Variations in reproductive traits at inflorescence and flower levels of an arctic legume, Astragalus alpinus L.: comparisons between a subalpine and an alpine population. Plant Species Biol 14:181-191. https://doi.org/10.104 6/j.1442-1984.1999.00012.x
Lüdecke D (2020) sjPlot: data visualization for statistics in social science. R package version 2.8.6. https://CRAN.R-project.org/packa $\mathrm{ge}=\mathrm{sjPlot}$

Maad J, Armbruster WS, Fenster CB (2013) Floral size variation in Campanula rotundifolia (Campanulaceae) along altitudinal gradients: patterns and possible selective mechanisms. Nor J Bot 31:361-371. https://doi.org/10.1111/j.1756-1051.2013.01766.x

Malo JE, Baonza J (2002) Are there predictable clines in plant-pollinator interactions along altitudinal gradients? The example of Cytisus scoparius (L.) Link in the Sierra de Guadarrama (Central Spain). Divers Distrib 8:365-371. https://doi.org/10.104 6/j.1472-4642.2002.00161.x

Mirek Z, Piękoś-Mirkowa H (1992) Plant cover of the Polish Tatra Mountains (S. Poland). Veröff. Geobot. Inst. ETH, Stiftung Rübel, Zürich, 107:177-199

Moreira X, Petry WK, Mooney KA, Rasmann S, Abdala-Roberts L (2018) Elevational gradients in plant defences and insect herbivory: recent advances in the field and prospects for future research. Ecography 41:1485-1496. https://doi.org/10.1111/ ecog.03184

Morente-López J, Scheepens JF, Lara-Romero C, Ruiz-Checa R, Tabarés P, Iriondo JM (2020) Past selection shaped phenological differentiation among populations at contrasting elevations in a Mediterranean alpine plant. Environ Exp Bot 170:103894. https://doi.org/10.1016/j.envexpbot.2019.103894

Nagy L, Grabherr G (2009) The biology of alpine habitats. Oxford University Press, Oxford

Ohara M, Higashi S (1994) Effects of inflorescence size on visits from pollinators and seed set of Corydalis ambigua (Papaveraceae). Oecologia 98:25-30. https://doi.org/10.1007/BF003 26086

Paudel BR, Dyer AG, Garcia JE, Shresta M (2019) The effect of elevational gradient on alpine gingers (Roscoeaalpina and R.purpurea) in the Himalayas. PeerJ 7:e7503. https://doi.org/10.7717/peerj .7503

Pérez-Harguindeguy N, Díaz S, Garnier E, Lavorel S, Poorter H, Jaureguiberry P, Bret-Harte MS, Cornwell WK, Craine JM, Gurvich DE, Urcelay C, Veneklaas EJ, Reich PB, Poorter L, Wright IJ, Ray P, Enrico L, Pausas JG, de Vos AC, Buchmann N, Funes G, Quétier F, Hodgson JG, Thompson K, Morgan HD, Ter Steege $\mathrm{H}$, vander Heijden MGA, Sack L, Blonder B, Poschlod P, Vaieretti MV, Conti G, Staver AC, Aquino S, Cornelissen JHC (2013) New handbook for standardised measurement of plant functional traits worldwide. Aust J Bot 61:167-234. https://doi.org/10.1071/ BT12225

Qi W, Bu H, Cornelissen JHC, Zhang C, Guo S, Wang J, Zhou X, Li W, Du G (2015) Untangling interacting mechanisms of seed mass variation with elevation: insights from the comparison of interspecific and intra-specific studies on eastern Tibetan angiosperm species. Plant Ecol 216:283-292. https://doi.org/10.1007/s1125 8-014-0435-7

R Core Team (2020) R: a language and environment for statistical computing. R Foundation for Statistical Computing, Vienna. https ://www.R-project.org/

Scheepens JF, Frei ES, Stöcklin J (2010) Genotypic and environmental variation in specific leaf area in a widespread Alpine plant after transplantation to different altitudes. Oecologia 164:141-150. https://doi.org/10.1007/s00442-010-1650-0

Scheidel U, Bruelheide H (2001) Altitudinal differences in herbivory on montane Compositae species. Oecologia 129:75-86. https:// doi.org/10.1007/s004420100695

Seguí J, Lázaro A, Traveset A, Salgado-Luarte C, Gianoli E (2018) Phenotypic and reproductive responses of an Andean violet to environmental variation across an elevational gradient. Alp Bot 128:59-69. https://doi.org/10.1007/s00035-017-0195-9 
Št'astná P, Klimešowá J, Doležal J (2012) Altitudinal changes in the growth and allometry of Rumex alpinus. Alp Bot 122:35-44. https ://doi.org/10.1007/s00035-012-0099-7

Takahashi K (2014) Effects of wind and thermal conditions on timberline formation in central Japan: a lattice model. Ecol Res 29:121131. https://doi.org/10.1007/s11284-014-1129-2

Takahashi K, Matsuki S (2016) Morphological variations of the Solidago virgaurea $\mathrm{L}$. complex along an elevational gradient on $\mathrm{Mt}$ Norikura, central Japan. Plant Species Biol 32:238-246. https:// doi.org/10.1111/1442-1984.12148

Theurillat J-P, Guisan A (2001) Potential impact of climate change on vegetation in the European Alps: a review. Clim Change 50:77109. https://doi.org/10.1023/A:1010632015572

Totland Ø (2001) Environment-dependent pollen limitation and selection on floral traits in an alpine species. Ecology 82:2233-2244. https://doi.org/10.1890/0012-9658(2001)082[2233:EDPLA $\mathrm{S}] 2.0 . \mathrm{CO} ; 2$

Totland $\varnothing$ (2004) No evidence for a role of pollinator discrimination in causing selection on flower size through female reproduction. Oikos 106:558-564. https://doi.org/10.111 1/j.0030-1299.2004.12991.x

von Arx G, Edwards PJ, Dietz H (2006) Evidence for life history changes in high-altitude populations of three perennial forbs. Ecology 87:665-674. https://doi.org/10.1890/05-1041

Weppler T, Stöcklin J (2006) Does pre-dispersal seed predation limit reproduction and population growth in the alpine clonal plant
Geum reptans? Plant Ecol 187:277-287. https://doi.org/10.1007/ s11258-006-9141-4

Wirth LR, Graf R, Gugerli F, Landergott U, Holderegger R (2010) Between-year variation in seed weights across altitudes in the high-alpine plant Eritrichum nanum. Plant Ecol 207:227-231. https://doi.org/10.1007/s11258-009-9667-3

Wu G, Tian F, Ren G, Liu Z (2011) Seed mass increase along altitude within four Saussurea (Asteraceae) species in Tibetian Plateau. Pol J Ecol 59:617-622

Zhao Z-G, Wang Y-K (2015) Selection by pollinators on floral traits in generalized Trollius ranunculoides (Ranunculaceae) along altitudinal gradients. PLoS ONE 10(2):e0118299. https://doi. org/10.1371/journal.pone.0118299

Zhu Y, Siegeolf RTW, Durka W, Körner Ch (2010) Phylogenetically balanced evidence for structural and carbon isotope responses in plants along elevational gradients. Oecologia 162:853-863. https ://doi.org/10.1007/s00442-009-1515-6

Publisher's Note Springer Nature remains neutral with regard to jurisdictional claims in published maps and institutional affiliations. 